Research Article

\title{
Optimization of Motorized Backpack Mistblower for Efficient Application of Insecticides against the Bagworm, Metisa plana Wallker
}

\section{Syed Mazuan, Syed Mohamed, Insyirah Ishak, Dzolkhifli Omar and Norhayu Asib*}

Department of Plant Protection, Faculty of Agriculture Universiti Putra Malaysia, 43400 UPM Serdang, Selangor.

Abstract | Oil Palm (Elaeis guineensis Jacq.) is a crucial economic crop in Malaysia which has become susceptible towards pests and diseases. Studies showed the major leaf defoliator of oil palm in Malaysia is the bagworm, Metisa plana. Various spraying methods had been developed for controlling the bagworms. A ground study was conducted in FELDA Gunung Besout 04, Perak, with its main focus on mistblower application towards bagworms. Stihl SR420 mistblower was characterised by having $1.2 \mathrm{~L} / \mathrm{min}$ flow rate, produced volume median diameter of $80 \mu \mathrm{m}$, and achieved spraying productivity of 2.58 hectares' land size (approximately 350 oil palms) per man day. The study was to evaluate the efficacy of chlorantraniliprole (Altacor ${ }^{\circ}$ 34.9WG), Bacillus thuringiensis kurstaki ( $\mathrm{DiPel}^{\circledR} \mathrm{ES}$ ), cypermethrin (Hextar Cyper 5.5EC), flubendiamide (Takumi ${ }^{\circledast}$ 20WG) and B. thuringiensis MPOB Bt-1 (Ecobac-1 EC). The insecticides application rate was based on the manufacturer's recommendation. The bagworms were monitored before treatment and at 3 , $7,15,30,45$, and 70 days after treatment (DAT). Post-census showed that all insecticides were able to reduce the bagworm population below the economic threshold level (10 larvae/ frond) within 15 DAT. Both cypermethrin and MPOB Bt1 resulted in the highest mortality of bagworms which was $83 \%$. Then, flubendiamide, chlorantraniliprole and Btk resulted in mortality rate of $82 \%, 75 \%$, and $70 \%$ respectively. All aforementioned, insecticides applied were able to suppress the population up to 30 DAT.

Received | March 24, 2020; Accepted | March 15, 2020; Published | June 05, 2021

*Correspondence | Norhayu Asib, Department of Plant Protection, Faculty of Agriculture Universiti Putra Malaysia, 43400 UPM Serdang, Selangor; Email: norhayuasib@upm.edu.my

Citation | Mohamed, S.M.S., I. Ishak, D. Omar and N. Asib. 2021. Optimization of motorized backpack mistblower for efficient application of insecticides against the bagworm, Metisa plana walker. Pakistan Journal of Agricultural Research, 34(2): 479-485.

DOI | http://dx.doi.org/10.17582/journal.pjar/2021/34.2.479.485

Keywords | Mistblower, Bagworm, Insecticides, Field application, Oil palm

\section{Introduction}

$\mathrm{O}$ il palm (Palmae: Elaeis guineensis Jacquin) was originated from West Africa and brought into South-East Asia early of the $20^{\text {th }}$ Century. It was first introduced as an ornamental plant in Malaysia, originated from Bogor, Indonesia (Arnott, 1963). Oil palm is one of the major crops in Malaysia yielded threefold oil more than coconut (Nair, 2010). The development of agricultural industry has improved people socioeconomic and lifestyle progressively. In 2016, total oil palm planted area was 5.74 million hectares, with $12.3 \%$ planted area belongs to FELDA Malaysian Palm Oil Board (MPOB, 2016). One of the major pests attacking oil palm severely is leafeating caterpillars for example bagworm, neetle and moth caterpillars. The bagworm, Metisa plana, is a significant leaf defoliator in Malaysian oil palm plantations (Basri et al., 1988). Metisa plana causes damage by feeding on young leaves of oil palm. The infestation may happen rapidly since their life cycle are shot thus reproduction rates are high (Priwiratama et al., 2018). Moderate defoliation by bagworm can cause declining in yield around 30June 2021 | Volume 34 | Issue 2 | Page 479 
$40 \%$ at the first year and second year after defoliation (Basri,1993; Kamarudin and Wahid, 2010; Potineni and Saravanan, 2013).

Chemical control has been used widely to prevent outbreak and to lower the bagworm population below economic threshold level (ETL). ETL is a condition where pest population density should be managed from increasing and contributing to economic dropping (Stern et al., 1959; Higley and Boethel, 1996). The advancement of Integrated Pest Management (IPM) encourages the use of selective chemicals on target pests while maintaining the safe of natural enemies (Wood,1971). Chemical control is speedy and practical to defeat the $M$. plana during the population outbreaks (Yap, 2000). There are numerous ways for applying insecticides towards the oil palm such as ground spraying, trunk injection, aerial spraying and root absorption. Usually, knapsack sprayer will be used to control bagworm populations by spraying the pesticides from the ground (Sudarsono et al., 2011). In combating bagworms, ground spraying provides higher spray deposition compared to aerial application whereas increasing in plant height can reduce the tendency of spray deposition (Nansen et al., 2011). Study in optimising the handling of motorized backpack mistblower and efficacy of applied insecticides using mistblower against $M$. plana in the field should be conducted to reduce $M$. plana population in the young oil palm plantation. In addition, two novel insecticides comprising of chlorantraniliprole and flubendiamide that believed to have a potential of controlling $M$. plana and environmentally friendly will be assessed throughout this study.

\section{Materials and Methods}

The study was conducted at FELDA Gunung Besout 04 oil palm plantation located in Sungkai, Perak with the total area of 878.11 hectares. The average age of oil palm was six years old and heights vary within 6 to 7 metres. Three areas were selected, separated by geographical terrain. Each area selected was divided into six treatment plots including a control plot (Figure 1). Each treatment plot consisted of 72 palms and another two rows as buffer zone.

Stihl SR 420 Motorised Backpack Mistblower was used for the spraying application. Proper calibration was conducted to evaluate the spraying pattern, spraying duration, best nozzle restrictor and the flow rate of mistblower. Each insecticides usage for spraying application was according to the manufacturer's recommendation rates (Table 1). Each solution was added with surfactant of Miracle S240 ${ }^{\mathrm{TM}}$ and fluorescence tracer at $0.0025 \% \mathrm{w} / \mathrm{v}$. Formula for pesticide spray as below (Mazuan, 2018).

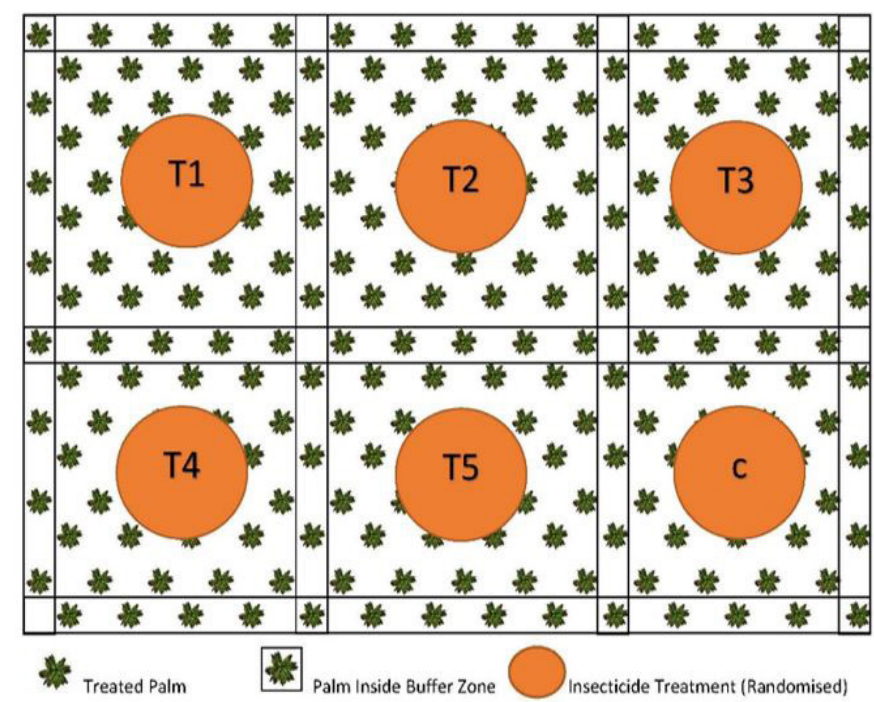

Figure 1: Experimental design in RCBD for one block area (consisted of 432 palms).

Table 1: Insecticides and recommendation rates per hectare.

\begin{tabular}{|c|c|c|c|}
\hline $\begin{array}{l}\text { Treatment } \\
\text { code }\end{array}$ & $\begin{array}{l}\text { Active Ingredi- } \\
\text { ent (A.I) }\end{array}$ & $\begin{array}{l}\text { Manufacturer's } \\
\text { brand }\end{array}$ & $\begin{array}{l}\text { Recommended } \\
\text { Rate/ ha }\end{array}$ \\
\hline $\mathrm{T} 1$ & $\begin{array}{l}\text { Chlorantra- } \\
\text { niliprole }\end{array}$ & $\begin{array}{l}\text { Altacor } 34.9 \\
\text { WG }\end{array}$ & $60 \mathrm{~g}$ \\
\hline $\mathrm{T} 2$ & $\begin{array}{l}\text { B. thuringiensis } \\
\text { kurstaki }\end{array}$ & $\mathrm{DiPel}^{\circledR} \mathrm{ES}$ & $1 \mathrm{~L}$ \\
\hline T3 & Cypermethrin & $\begin{array}{l}\text { Hextar Cyper } \\
5.5 \mathrm{EC}\end{array}$ & $1 \mathrm{~L}$ \\
\hline $\mathrm{T} 4$ & Flubendiamide & Takumi $^{\oplus} 20 \mathrm{WG}$ & $100 \mathrm{~g}$ \\
\hline T5 & $\begin{array}{l}\text { B. thuringiensis } \\
\text { MPOB Bt1 }\end{array}$ & Ecobac-1 EC & $3 \mathrm{~L}$ \\
\hline T6 & Water & Control & - \\
\hline
\end{tabular}

Spray volume $(L / h a)=$ flow rate $(L / \mathrm{min}) x$ Spray duration in one hectare ( $\mathrm{min} / \mathrm{ha}$ )

Spraying application= Recommended insecticide (unit) hectare) x spray volume (L/hectares)

The efficacy of insecticides was evaluated by assessing the number of $M$. plana before treatment application in comparison to post-treatment. Posttreatment census was conducted at 3, 7, 15, 30, 45 and 60 days. The census of bagworm was conducted by pruning one frond or the upper frond that had 
sign of bagworm attack with inclination of $45^{\circ}$. According to best practice, bagworm attack will be clearly shown at frond number 17 and thus it will be selected for pruning. Subsequently, the number of $M$. plana was counted on every surface of the frond according to larval stages. Upon the completion of spray treatment, sampling made by randomly select one leaf from each frond section at proximal, middle and distal from three scattered trees at each sprayed area. The collected samples were analysed for spray deposition by using fluorometer. Analysis of Variance (ANOVA) was used to examine the collected data at $p=0.05$. Tukey's multiple range test was used to further distinguish the means in SAS computer package (SAS 9.4).

\section{Results and Discussion}

Spraying application with Stihl SR420 mistblower was conducted based on $110 \mathrm{~L}$ spray volume, 40 seconds spraying time and restrictor 3. It was concluded that vertical zig-zag movement following the frond shape was the optimum technique to maximise the droplet distribution (Mazuan, 2018). Mist spraying followed by constant vertical direction towards the frond provides maximum coverage of droplet distribution towards the target area, thereby minimising the impact towards non-targeted insects. $1.2 \mathrm{~L}$ per minutes flow rate was produced with the volume median diameter (VMD) of $80 \mu \mathrm{m}$ (very fine droplet) (Table 2). A worker was estimated to spray at 3.1 hours per hectare (10 minutes for refill and resting time) and projected to cover 2.58 hectares in one day. A team of five sprayed roughly 13 hectares per day which equivalent to 77.4 hectares per week (Mazuan, 2018).

Table 2: Calculation of mistblower application per man day.

\begin{tabular}{|c|c|c|}
\hline Sprayer & $\begin{array}{ll}\text { Tank } & \text { Litre per } \\
\text { size } & \text { hectares }\end{array}$ & Flow rate $(\mathrm{L} / \mathrm{min})$ \\
\hline $\begin{array}{l}\text { Mistblower Stihl } \\
\text { SR420 }\end{array}$ & $12 \mathrm{~L} \quad 110 \mathrm{~L}$ & $1.20 \pm 0.006$ \\
\hline $\begin{array}{l}\text { Time needed to } \\
\text { spray one hectare }\end{array}$ & Number of refill & $\begin{array}{l}\text { Time needed for refill } \\
+ \text { resting time }\end{array}$ \\
\hline 1.53 hours & 10 & 10 minutes \\
\hline $\begin{array}{l}\text { Overall time spray / } \\
\text { hectares }\end{array}$ & 3.1 hours & \\
\hline Working hours & 8 hours & \\
\hline $\begin{array}{l}\text { Total areas covered } \\
\text { (man day) }\end{array}$ & 2.58 hectares & \\
\hline
\end{tabular}

Standard curve of fluorescence concentration was plotted to determine the fluorescence concentration based on the fluorometer reading. The mean concentration of spray depositions (Table 3) showed that there is no significant difference between each treatment $(\mathrm{F}=1.94$, d. $\mathrm{f}=4, \mathrm{P}=0.1073)$. Therefore, the results showed that the distribution of droplets was constant on all the treatment plots (Figure 2).

Table 3: Mean concentration of spray deposition in each treatment plot.

\section{Treatment}

Cypermethrin

B. thuringiensis kurstaki

Flubendiamide

B. thuringiensis MPOB Bt1

Chlorantraniliprole

$\mathrm{F}$ value

$P$ value

\section{Mean Concentration $\left(\mu \mathrm{gl}^{-1}\right)$} $\pm \mathrm{SE}$

$5.01 \times 10^{-4} \pm 1.70 \times 10^{-4}$

$3.82 \times 10^{-4} \pm 3.64 \times 10^{-5}$

$7.75 \times 10^{-4} \pm 1.08 \times 10^{-4}$

$3.97 \times 10^{-4} \pm 1.03 \times 10^{-4}$

$6.04 \times 10^{-4} \pm 1.03 \times 10^{-4}$

1.94

0.1073

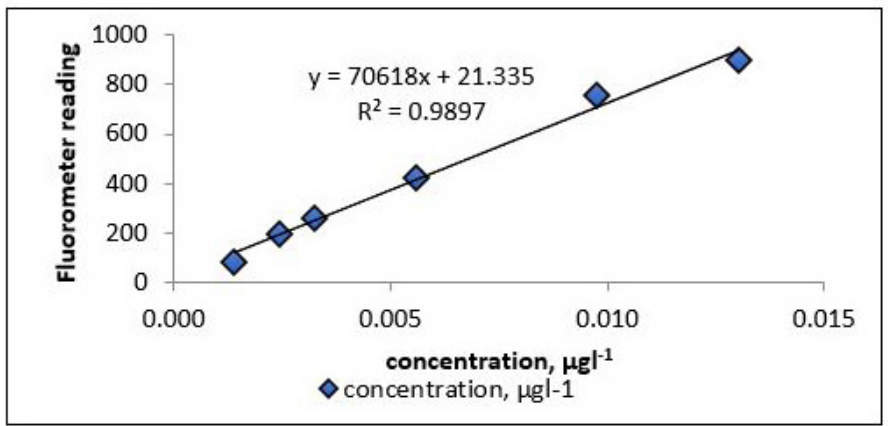

Figure 2: Standard curve of fluorescence concentration.

Note: Mean followed by similar letter in the same column are not significantly different after Tukey's multiple test at 95\% confidence level. Number in brackets are the percentage reduction of bagworm (\%) on selected DAT.

Bagworm census is a core activity need to be conducted in every bagworm's attack. The purpose is to identify the bagworm species, and to monitor the attackedinfestation area. Pre-assessment was conducted in the study area to find the suitable period in which the bagworm larvae were within early instars to improve reliability of the result. Therefore, $M$. plana was shown to be dominant, and only the species that was counted and recorded for this experiment. Based on the census conducted, the means number of $M$. plana among the treatment was significantly different at various assessment days (Table 4).

The population of $M$. plana was shown to have a significant reduction in all treatment plots as early

June 2021 | Volume 34 | Issue 2 | Page 481 
as 3 DAT. The mortality rate of $M$. plana shown the highest at chlorantraniliprole (50\%), as compare to rest of other treatments. Population of $M$. plana had showed a slight reduction in control plot by $2 \%$. Means population in treatment plot was significantly different to each other $(\mathrm{F}=6.60$, d.f $=5, \mathrm{P}<0.001)$.

The population of $M$. plana had reduced below Economic Threshold Level (ETL) at 15 DAT for all the evaluated insecticides. Population declined was shown to be at approximately $80 \%$ from the initial number before the treatment. The ETL showed a sign of critical level for the maximum number of bagworm's larvae to live underneath of one frond. The ETL for bagworm species of $M$. plana is 10 larvae per frond. Natural enemies were sufficient to control the population from outbreak occurrence, given usual ecological practises, so the population counted below the ETL was considered negligible (Wood, 1971; Hoong and Hoh, 1992).

The population of $M$. plana remained below ETL at 30 DAT (Figure 3). However, showed sign of population growth at 45 DAT for chlorantraniliprole and Btk. Nonetheless, the population of $M$. plana in flubendiamide, cypermethrin and MPOB Bt-1 was keep dropping, and remained below ETL. The highest mortality rate of $M$. plana was flubendiamide (97\%) followed by cypermethrin (95\%), MPOB Bt1 (87\%), chlorantraniliprole (70\%) and Btk (62\%).
Population in control plot was maintained above the ETL. Mortality of the bagworm's population was observed in the control plots, which can be assumed due to the biotic and abiotic factors. The biotic factors exemplified as various beneficial insects that acted as predators or parasitoids to the bagworms larvae or adults.

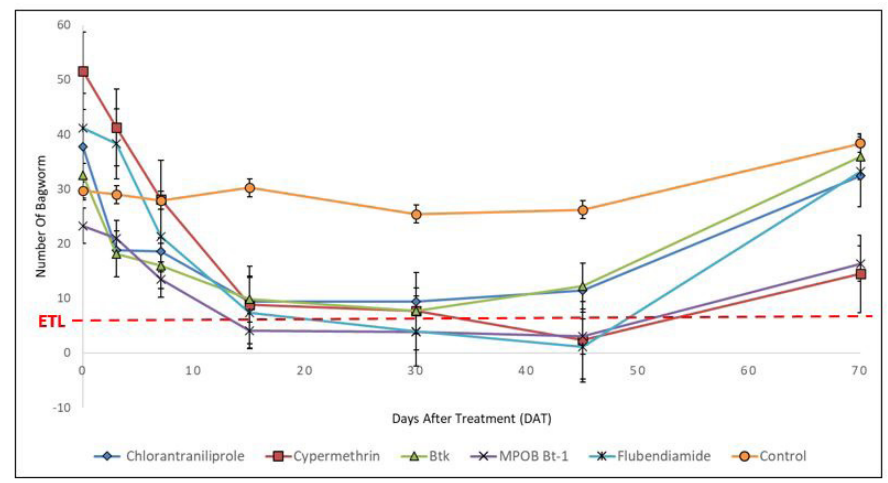

Figure 3: The mean number of bagworms over days of treatment. Note: Economic Threshold Level (ETL) of 10 larvael frond (Wood,1971; Hoong and Hoh, 1992).

Bagworm management may be aided by biological control using natural enemies such as bacteria, parasitoids, and predators (Ramlah et al., 2003; Cheong et al., 2010). For instance, various biological control agents such as Cotesia (=Apanteles) metesae, Cosmelestes picticeps (Hemiptera: Reduviidae) and Dolichogenidea metasae (Hymenoptera: Braconidae) were applied to manage the bagworms.

Table 4: Mean population and percentage mortality of $M$. Plana at each DAT after treatment application.

\begin{tabular}{|c|c|c|c|c|c|c|c|c|c|c|c|}
\hline \multirow{2}{*}{$\begin{array}{l}\text { Treatment } \\
\text { (Active ingredient) }\end{array}$} & \multicolumn{11}{|c|}{ Means population of $\mathrm{m}$. plana over day of treatment } \\
\hline & Pre-census & 3 DAT & & $7 \mathrm{DAT}$ & 15DAT & & 30DAT & & 45DAT & & 70DAT \\
\hline \multirow[t]{2}{*}{ Chlorantraniliprole } & $37.77 \pm 4.05 \mathrm{abc}$ & $18.83 \pm 2.27$ & $\mathrm{~b}$ & $18.63 \pm 2.04 \mathrm{ab}$ & $9.37 \pm 4.17$ & $\mathrm{~b}$ & $9.43 \pm 0.47$ & $\mathrm{~b}$ & $11.47 \pm 0.42$ & $\mathrm{~b}$ & $32.40 \pm 5.81 \mathrm{ab}$ \\
\hline & & $(50 \%)$ & & $(51 \%)$ & $(75 \%)$ & & $(75 \%)$ & & $(70 \%)$ & & $(14 \%)$ \\
\hline \multirow{2}{*}{$\begin{array}{l}\text { Bacillus thuringien- } \\
\text { sis kurstaki }\end{array}$} & $32.50 \pm 3.16 \mathrm{bc}$ & $18.17 \pm 1.77$ & $\mathrm{~b}$ & $15.93 \pm 1.59 \mathrm{ab}$ & $9.83 \pm 3.55$ & $\mathrm{~b}$ & $7.73 \pm 0.63$ & bc & $12.20 \pm 0.59$ & $\mathrm{~b}$ & $35.93 \pm 4.42 \mathrm{a}$ \\
\hline & & $(44 \%)$ & & $(51 \%)$ & $(70 \%)$ & & $(76 \%)$ & & $(62 \%)$ & & $11 \%$ \\
\hline \multirow[t]{2}{*}{ Cypermethrin } & $51.60 \pm 5.26 \mathrm{a}$ & $41.27 \pm 4.52$ & $\mathrm{a}$ & $28.17 \pm 4.56 \quad \mathrm{a}$ & $8.83 \pm 4.87$ & $\mathrm{~b}$ & $7.67 \pm 1.03$ & $\mathrm{bc}$ & $2.33 \pm 0.63$ & $\mathrm{c}$ & $14.47 \pm 4.34 \mathrm{c}$ \\
\hline & & $(20 \%)$ & & $(45 \%)$ & $(83 \%)$ & & $(85 \%)$ & & $(95 \%)$ & & $(72 \%)$ \\
\hline \multirow[t]{2}{*}{ Flubendiamide } & $41.13 \pm 6.45 \mathrm{ab}$ & $38.30 \pm 5.94$ & $\mathrm{a}$ & $21.30 \pm 3.98 \mathrm{ab}$ & $7.37 \pm 6.75$ & $\mathrm{~b}$ & $4.00 \pm 0.79$ & $\mathrm{c}$ & $1.10 \pm 0.39$ & c & $33.20 \pm 3.02 \mathrm{a}$ \\
\hline & & $(7 \%)$ & & $(48 \%)$ & $(82 \%)$ & & $(90 \%)$ & & $(97 \%)$ & & $(19 \%)$ \\
\hline \multirow{2}{*}{$\begin{array}{l}\text { Bacillus thuringiensis } \\
\text { MPOB Bt1 }\end{array}$} & $23.27 \pm 5.79 \mathrm{c}$ & $21.00 \pm 3.89$ & $\mathrm{~b}$ & $13.43 \pm 2.17 \mathrm{~b}$ & $4.07 \pm 5.86$ & $\mathrm{~b}$ & $3.80 \pm 1.01$ & $\mathrm{c}$ & $3.03 \pm 0.91$ & c & $16.33 \pm 2.88 \mathrm{bc}$ \\
\hline & & $(10 \%)$ & & $(42 \%)$ & $(83 \%)$ & & $(84 \%)$ & & $(87 \%)$ & & $(30 \%)$ \\
\hline \multirow[t]{2}{*}{ Control } & $29.67 \pm 2.98 \mathrm{bc}$ & $28.97 \pm 3.34$ & $\mathrm{ab}$ & $27.93 \pm 3.71 \mathrm{a}$ & $30.23 \pm 3.13$ & $\mathrm{a}$ & $25.43 \pm 1.56$ & $\mathrm{a}$ & $26.23 \pm 1.24$ & $\mathrm{a}$ & $38.37 \pm 2.74$ a \\
\hline & & $(2 \%)$ & & $(6 \%)$ & $2 \%$ & & $(14 \%)$ & & $(12 \%)$ & & $29 \%$ \\
\hline $\begin{array}{l}\mathrm{F} \text { value } \\
\mathrm{P} \text { value }\end{array}$ & $\begin{array}{l}3.69 \\
0.0034\end{array}$ & $\begin{array}{l}6.60 \\
0.001\end{array}$ & & $\begin{array}{l}3.15 \\
0.0094\end{array}$ & $\begin{array}{l}37.45 \\
0.001\end{array}$ & & $\begin{array}{l}47.49 \\
0.001\end{array}$ & & $\begin{array}{l}71.51 \\
0.001\end{array}$ & & $\begin{array}{l}6.78 \\
0.001\end{array}$ \\
\hline
\end{tabular}


Cheong et al. (2010) reported despite the fact that entomopathogenic fungi such as Paecilomyces fumosoroseus and Metarbizium anisopliae have shown promising results in the laboratory, when used in the field, these EPF provided mixed results. In Perak, Malaysia Cheong et al. (2010) discovered predators were the leading cause of bagworm natural mortality, followed by parasitoids and fungal infections, with 37.0 percent, $35.9 \%$, and 27.2 percent, respectively, suppressing the bagworm population in the region.

At 70 DAT, all plots displayed a significant increase of population $M$. plana above the ETL. The rapid increased of $M$. plana population after the treatment showed that the biotic factors were unable to supress the existing population below the ETL. The reason may be due to the high application of broad-spectrum insecticides and a low number of beneficial plants in the field, which could damage the natural ecological of micro-environment.

The occurrence of multi-stages (instar) of larvae in study location might be another reason of recurring outbreak. Supposedly, the second treatment in the same area should be conducted at 45 DAT to control remerging of the population from late instar. The result of cypermethrin was the best among others but the broad-spectrum characteristic may damage the natural beneficial predators and parasitoids. Pyrethroids, on the other hand, have been designated as the most harmful insecticides to beneficial anthropods (Croft, 1990). Overall, nymphs of the predator were highly susceptible to the insecticides of cypermethrin, deltamethrin and dipterex (Farehan et al., 2013). The use of Bacillus thuringiensis however provided less adverse effect on the beneficial insects. Study conducted by Najib et al. (2009) showed that When high dose Bt-Teracon- ${ }^{\circledR}$ was administered to beneficial insects associated with Cassia cobanensis, it resulted in $25 \%$ mortality compared to $100 \%$ mortality when cypermethrin was used. As a result, B. thuringiensis was chosen because it has less side effects and has been shown to be pest specific.

Nonetheless, the existence of novel insecticides based on diamine class such as chlorantraniliprole and flubendiamide, provided a specific mode of action to Lepidopteran species. They can be the alternatives to biological insecticide $B$. thuringiensis because of the weakness of short life span, and easily degraded to the sunlight (Valent BioScience Corporation, 2014).

\section{Conclusions and Recommendations}

The study showed that the application of chlorantraniliprole, flubendiamide, Btk, MPOB Bt1 and cypermethrin were effective to control the population of $M$. plana significantly below the ETL of 10 larvae per frond within 15 DAT. Cypermethrin and MPOB Bt1 were recorded as the highest mortality of $M$. plana by $83 \%$, followed by flubendiamide, chlorantraniliprole and Btk. The insecticides were able to suppress the population of $M$. plana up to 30 DAT. However, $M$. plana population was increased slowly after 30 DAT indicated the second treatment should be applied to control the emergence of new larval population. The use of cypermethrin however, could potentially kill the beneficial insects and natural enemies of $M$. plana. Whilst $B$. thuringiensis was proven to be the pest-specific. Nevertheless, the novel chemical insecticides such as chlorantraniliprole and flubendiamide were claimed to be specific to Lepidopteran. Therefore, further study was suggested in observing the impact of these insecticides on beneficial insect E. kamerunicus, which was highly susceptible to the insecticides.

\section{Acknowledgements}

We would like to thank the Federal Land Development Authority (FELDA), Gunung Besout for granting us with the permission to conduct the field application at their oil palm plantation located in Sungkai, Perak, Malaysia.

\section{Novelty Statement}

Our study provides insightful and relevant data of two novel insecticides; chlorantraniliprole and flubendiamide against lepidopteran species at the field. Based on this study, both insecticides are promising alternatives to biological insecticides $\mathrm{B}$. thuringiensis.

\section{Author's Contribution}

Syed Mazuan and Syed Mohamed: Conceived the idea. Wrote abstract, methodology, data collection and analysis. Introduction, result, discussion, conclusion.

Insyirah Ishak: Overall management of the article.

Abstract, conclusion, references

Dzolkhifli Omar: Conceived the idea. Technical input.

Norhayu Asib: Conceived the idea, Overall 
management of the article and technical input.

\section{Conflict of interest}

The authors have declared no conflict of interest.

\section{References}

Arnott, G.W., 1963. The Malaysian oil palm and the analysis of its products. Department of Agriculture, Federation of Malaya. Div. Agric. Bull., 113(32).

Basri, M.W., A.H. Halim and M. Zulkifli. 1988. Bagworms (Lepidoptera: Psychidae) of oil palms in Malaysia. PORIM Occasional Paper, 23(3).

Basri, M.W., 1993. Life history, ecology and economic impact of the bagworm, Metisa plana Walker (Lepidoptera: Psychidae) on the oil palm Elaeis quineensis Jacquin (Palmae) in Malaysia. $\mathrm{PhD}$ thesis, University of Guelph, pp. 231.

Cheong, Y.L., A.S. Sajap, M.N. Hafidzi, D. Omar and F. Abood. 2010. Outbreaks of bagworms and their natural enemies in an oil palm, elaeis guineensis, plantation at Hutan Melintang, Perak, Malaysia. J. Entomol., 7(3): 141-151. https://doi.org/10.3923/je.2010.141.151

Croft, B.A., 1990. Arthropod Biological Control Agents and Pesticides. New York: Wiley.

Higley, L.G. and L.P. Pedigo. 1996. The EIL Concept. In: L.G. Higley and L.P. Pedigo (Eds.), Economic Thresholds for Integrated Pest Management, Lincoln: University of Nebraska Press. pp. 9-21.

Hoong, H.W. and C.K.Y. Ho. 1992. Major pests of oil palm and their occurrence in Sabah. Paper presented at the ISP Sabah North-East Branch Oil Palm Seminar, Sandakan Sabah, pp. 193210.

Kamarudin, N. and M.B. Wahid. 2010. Interactions of the bagworm, Pteroma pendula (Lepidoptera: Psychidae), and its natural enemies in an oil palm plantation in Perak. J. Oil Palm Res., 22(April): 758-764.

Malaysian Palm Oil Board. 2016. Oil palm planted area 2016. Retrieved from http://bepi.mpob. gov.my/index.php/my/statistics/area/176area-2016/790-oil-palm-planted-area-as-atdec-2016.html.

Najib, M.A., A.S. Ramlah, A.M. Mazmira and W.M. Basri. 2009. Effect of Bacillus thuringiensis, Terakil-1 and Teracon-1 against oil palm pollinator, Elaeidobius kamerunicus and beneficial insects associated with Cassia cobanensis. J. Oil Palm Res., 21: 667-674.

Nair, K.P.P., 2010. Oil Palm (Elaeis guineensis Jacquin). The agronomy and economy of important tree crops of the developing world, pp. 209-236. https://doi.org/10.1016/B978-012-384677-8.00007-2

Nansen, C., K.Vaughn, Y.Xue, C.Rush, F.Workneh, J. Goolsby and X. Martini. 2011. A decisionsupport tool to predict spray deposition of insecticides in commercial potato fields and its implications for their performance. J. Econ. Entomol., 104(4): 1138-1145. https://doi. org/10.1603/EC10452

Farehan, N.I., R. Syarafina and A.B. Idris. 2013. Toxicity of three insecticides on the predator of oil palm leaf-eater pests Sycanus dichotomus Stal. (Hemiptera:Reduviidae). Acad. J. Entomol., 6(1): 11-19.

Potineni, K. and L. Saravanan. 2013. Natural enemies of oil palm defoliators and their impact on pest population. Pest Manage. Hortic. Ecosyst., 19(2): 179-184.

Priwiratama, H., A.E. Prasetyo and A. Susanto. 2018. Biological control of oil palm insect pests in Indonesia. Conference: The $19^{\text {th }}$ International Oil Palm Conference, Cartagena, Columbia.

Ramlah, A.S., M.W. Basri and N.M. Mahadi. 2003. Proceedings of the PIPOC 2003 international palm oil congress, agriculture conference. Banggi: MPOB; 2003. Aug 20-23, 2001. IPM of bagworms and Nettle caterpillars using Bacillus thringiensis: Towards increasing efficacy; Kuala Lumpur. pp. 449-474.

Stern, V.M., R.F. Smith, R. van den Bosch and K.S. Hagen. 1959. The integrated control concept. Hilgardia, 29: 81-101. https://doi.org/10.3733/ hilg.v29n02p081

Sudarsono, H., P. Purnomo and A.M. Hariri. 2011. Population assessment and appropriate spraying technique to control the bagworm (Metisa plana Walker) in North Sumatra and Lampung. AGRIVITA J. Agric. Sci., 33(2): 188-198.

Mazuan, S.M., 2018. Efficacy of five insecticides against bagworm, Metisa plana Walker and their side effects on oil palm pollinator, Elaeidobius kamerunicus Faust (Master's thesis). Universiti Putra Malaysia. 
Valent Bioscience Corporation, 2014. Dipel ES Biological Insecticide; Arial Application in Oil Palm (Brochure), Australia.

Wood,B.J.,1971.Development of integrated control programs for pests of tropical perennial crops in Malaysia. In: C.B. Huffaker (Ed.). Biol. Contr., pp. 422-457. https://doi.org/10.1007/978-14615-6531-4_19

Yap, T.H., 2000. The intelligent management of Lepidoptera leaf eaters in mature oil palm by trunk injection (a review of principles) The Planter, 76(887): 99-107. 